\title{
LES MÉDIATEURS NEURONAUX CHEZ LES MONOGÈNES
}

\author{
D. W. HALTON (1), A. G. MAULE (2), C. SHAW (2)
}

(1) The Queen's University of Belfast, Comparative Neuroendocrinology Research Group, School of Biology \& Biochemistry.

(2) Belfast BT7 1NN, School of Clinical. Medicine, Northern Ireland, U.K.

\section{RÉSUMÉ}

Comme les autres plathelminthes, les Monogènes sont riches en substances neuroactives. En plus des composants neuronaux aminergiques et cholinergiques à action rapide, impliqués dans la régulation des réponses sensorielles chez les vers, existent en grand nombre des éléments peptidergiques à action lente. Ceux-ci interviennent probablement dans la régulation à plus long terme des réactions et des comportements.

En utilisant des techniques immunochimiques, on a pu mettre en évidence à ce jour jusqu'à 10 immunoréactions régulatrices peptidiques chez le Monogène Diclidophora merlangi. Parmi ces peptides, le neuropeptide F (NPF) est de loin le plus abondant, ce qui conforte les observations déjà faites chez les représentants des principaux phyllums d'invertébrés étudiés. Chez D. merlangi., le NPF se trouve largement réparti dans les structures nerveuses centrale et périphérique, y compris celles liées à l'appareil reproducteur. De plus, dans l'appareil reproducteur femelle, l'innervation des muscles responsables des séries de contractions-relaxations nécessaires à l'accumulation des oeufs semble être exclusivement peptidergique.

Tandis que les propriétés fonctionnelles du NPF doivent être maintenant déterminées, sa localisation intracellulaire au niveau des jonctions neuromusculaires de l'ootype chez $D$. merlangi étaye l'hypothèse d'une intervention peptidergique dans la fonction reproductive, et plus précisement dans la coordination des séquences présidant à la formation de l'oeuf.

\section{NEURONAL MEDIATORS IN MONOGENEAN PARASITES}

\begin{abstract}
In common with other flatworms, monogenean parasites are rich in neuroactive substances. In addition to the classical fast-acting cholinergic and aminergic neuronal components, involved in regulating motor activity and perhaps mediating sensory responses in the worms, are numerous, slow-acting peptidergic elements that possibly mediate much longer term events and behaviours. Using immunochemical procedures, as many as 10 regulatory peptide immunoreactivities have been demonstrated to date in the monogenean, Diclidophora merlangi. Of these peptides, by far the most abundant is neuropeptide F (NPF), a finding which is consistent with the observations in representatives of all major invertebrate phyla investigated. In D. merlangi, NPF occurs extensively throughout central and peripheral nerve elements, including those of the reproductive system. Moreover, in the female reproductive system, the innervation of the duct muscles that are responsible for the highly-ordered series of contractions and relaxations essential in egg assembly, appears to be exclusively peptidergic. While the functional properties of NPF have yet to be determined, its subcellular localisation at neu romuscular junctions in the egg-forming apparatus of $D$. merlangisupports a peptidergic involvement in reproductive function, perhaps in coordinating the cyclical sequence of muscle contractility involved in egg formation.
\end{abstract}




\section{INTRODUCTION}

Most monogeneans (with the notable exception of the endoparasitic polystomatids of tetrapods) infest the skin or gills of fishes and, as ectoparasites, have a well-developed neuromuscular system. This enables them to cling to the host in the face of water currents and to feed on a diet of skin and its secretions, or on blood derived from the vascularised gill lamellae. Many monogeneans are quite mobile and capable of moving over the surface of the fish host. Both anterior and posterior (haptor) adhesive organs, as well as the pharynx (feeding organ) and general body musculature, are richly innervated with nerve fibres that may be motor, or at least modulatory, in function and which presumably serve to coordinate the behavioural activities involved in attachment, migration, feeding, and insemination. Monogeneans also seem well able to perceive and respond to a wide-range of environmental cues, through an extensive peripheral system of sensory nerves and associated receptors.

While cytochemical information on the monogenean nervous system is fragmentary, what is available provides good evidence for the presence of several putative neurotransmitters and neuromodulators in a number of genera (Table I). Much of the data has come from the application of the techniques of immunochemistry and the discovery in invertebrates of homologues to recognised vertebrate messenger molecules known as regulatory peptides. Moreover, these findings support what is now being recognised for many other invertebrate groups: that the platyhelminth nervous system has a multifunctional secretory role in homeostasis by serving to coordinate not only the parasite's repertoire of complex behavioural activities, but also many of the physicochemical processes associated with its growth and reproductive development (HALTON et al., 1992; GUSTAFSSON, 1992).

\section{Tableau I : Médiateurs neuronaux potentiels identifiés chez les Monogènes.}

Table I : Putative neuronal mediators identified in monogenean parasites.

\begin{tabular}{lcccccc}
\hline & ACh & $5-\mathrm{HT}$ & Dop & NAdr & Adr & $\begin{array}{c}\text { Peptides } \\
(\mathrm{N})\end{array}$ \\
\hline Gyrodactylus $(1,2)$ & + & + & - & - & - & $+(4)$ \\
Microcotyle $(3,4)$ & - & - & + & + & + & - \\
Diplozoon $(5)$ & + & - & - & - & - & - \\
Eudiplozoon $(6)$ & - & + & - & - & - & - \\
Diclidophora $(7,8,9,10)$ & + & + & - & - & - & $+(10)$ \\
Polystoma $(11,12,13)$ & + & + & + & + & - & $+(1)$ \\
Protopolystoma $(13)$ & + & + & - & - & - & $+(1)$ \\
\hline
\end{tabular}

Key : ACh, acetylcholine; 5-HT, 5-hydroxytryptamine ; Dop, dopamine ; NAdr, noradrenaline ; Adr, adrenaline

* Indirect evidence from cholinesterase staining ; $N=$ number of peptides demonstrated ; + , present ; -, not investigated.

References:

(1) REUTER (1987); (2) REUTER (1988); (3) GUSTAFSSON (1990); (4) TIEKOTTER (1988) ; (5) HALTON \& JENNINGS (1964); (6) LYUKSHINA \& SHISHOV (1988); (7) HALTON \& MORRIS (1969); (8) HALTON et al. (1987); (9) MAULE et al. (1990b) ; (10) MAULE et al. (1992b) ; (11) RAHEMO \& GORGEES (1987); (12) TERENINA \& OVERCHUK (1988); (13) McKAY et al. (1991). 
Of the relatively few monogeneans that have been examined neurochemically, perhaps the best researched is the polyopisthocotylean Diclidophora merlangi, a bloodfeeding gill parasite of the whiting, Merlangius merlangus (Fig. 1). Using data derived from $D$. merlangi, this paper reviews the present knowledge of putative messenger molecules in the monogenean flatworms, paying particular attention to neuropeptides and their presence in the reproductive apparatus of these parasites.

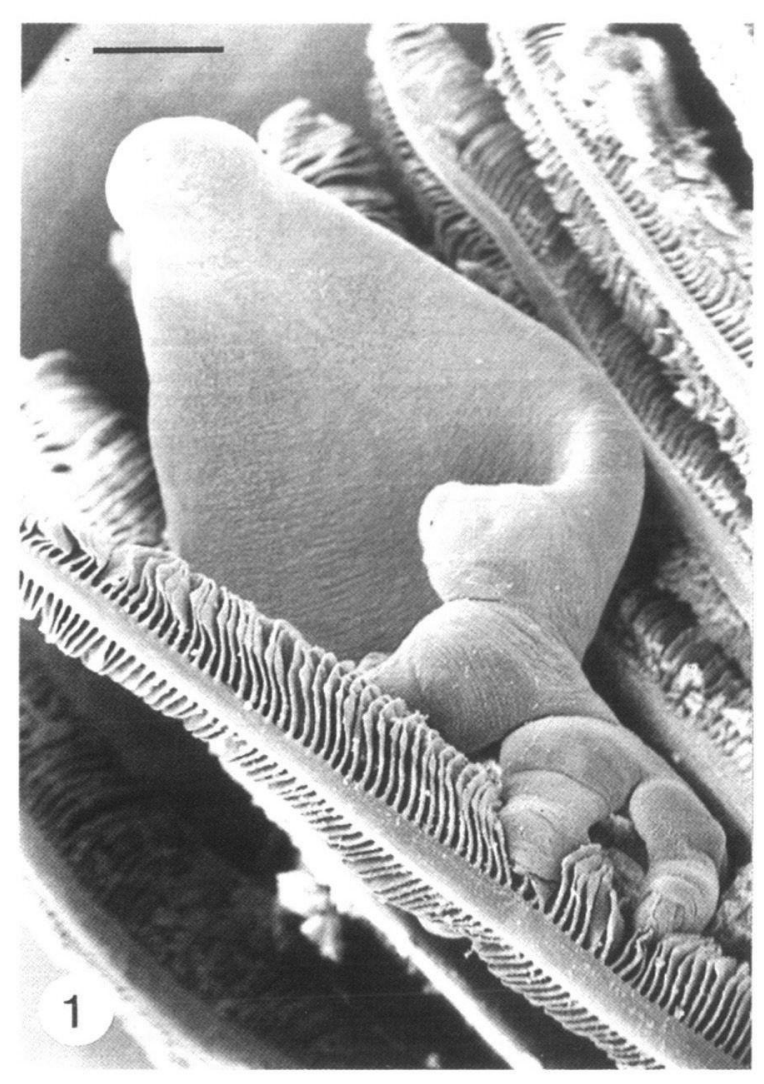

Figure 1 : Diclidophora merlangi sur les branchies du merlan (Merlangius merlangus) vu au microscope électronique à balayage.

Figure 1 : Diclidophora merlangi on the gills of the whiting (Merlangius merlangus) as seen by scanning electron microscopy. The adhesive attitude of the worm is determined by the 8 pincer-like clamps of the haptor that secure the parasite to the secondary gill lamellae of its fish host, so that the forebody of the parasite lies downstream relative to the gill-ventilating water current. Scale bar, $0.5 \mathrm{~mm}$.

\section{MONOGENEAN NERVOUS SYSTEM}

\section{Gross structure}

Staining based on the indoxyl acetate or acetylthiocholine iodide methods for demonstrating cholinesterase activity provided a breakthrough in delineating nerve elements from the surrounding parenchymatous tissue in the acoelomate flatworm parasite (HALTON \& JENNINGS, 1964; HALTON \& MORRIS, 1969). Using this histochemical methodology on whole-mount preparations of worms has helped greatly in establishing the anatomical details of the monogenean nervous system in toto (Fig. 2). 


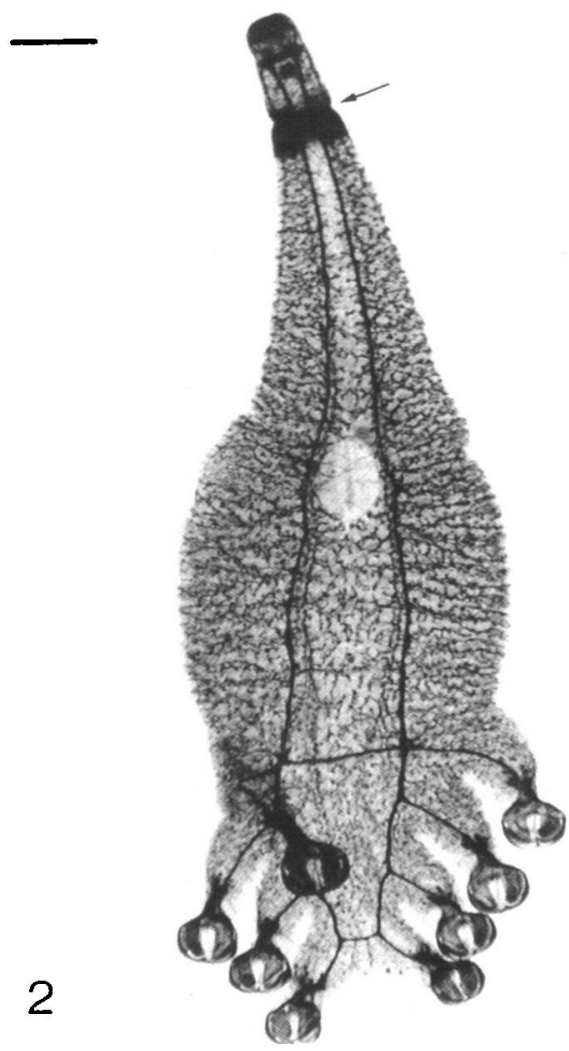

Figure 2 : Préparation et coloration "in toto" de $D$. merlangi mettant en évidence l'activité cholinesterase (ChE) dans le système nerveux central et périphérique.

Figure 2 : Whole-mount preparation of $D$. merlangi stained to demonstrate cholinesterase (ChE) activity in the central and peripheral nervous systems. Note the prominant ventral longitudinal nerve cords and their innervation of the 8 clamps; also the "collar" of reaction product (arrow) that marks the nerve plexus of the forebody. Scale bar, $0.8 \mathrm{~mm}$.

Flatworms are the first animals of organ-grade construction to have developed a central nervous system (CNS), and as such most of them display a moderate degree of neurocephalisation. Essentially, the CNS of $D$. merlangi consists of a rudimentary brain, comprising two cerebral ganglionic collections of nerve cells linked by a commissure, together with a well-differentiated orthogonal arrangement of associated longitudinal nerve cords cross-linked by numerous transverse connectives (Fig. 2). There are three pairs of longitudinal cords (ventral, dorsal and lateral), of which the ventral are the best developed. At the level of the haptor, the ventral cords provide nerve roots that extend into each of the 8 peduncles where, supported by a ganglionic mass of neurones, they each divide and anastomose into a network of fine fibres innervating the clamp musculature (Figs. 2, 4).

From the brain, numerous nerves radiate to the pharynx, the buccal suckers, and to the margins and sense organs of the mouth; connections to the gonopore region provide a rich innervation to the muscle of the armed penis (Fig. 3). In the forebody of the worm, the lateral nerve cords run from each of the cerebral ganglia and connect with a well-developed plexus of interconnecting cell bodies that encircles the "neck" region of the worm, innervating the subtegumental muscle in this region (Fig. 2). The forebody of $D$. merlangi is a highly motile 


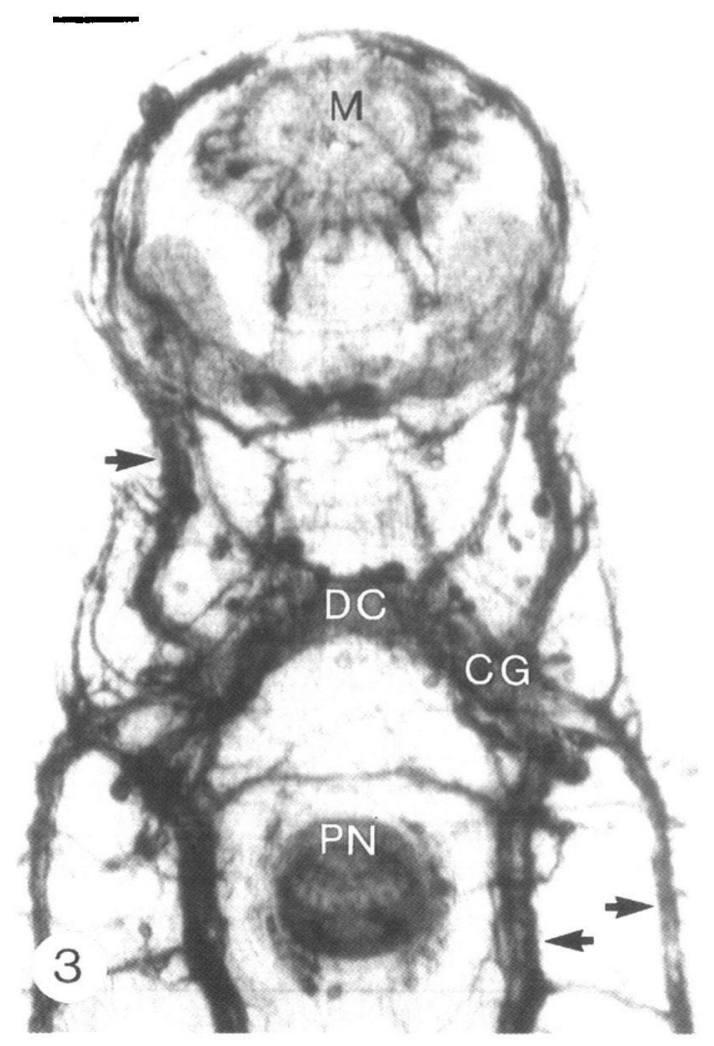

Figure 3 : Activité ChE dans la région antérieure de $D$. merlangi montrant ses relations avec le ganglion cérébral, la commissure dorsale, et les cordons nerveux longitudinaux antérieurs et postérieurs (flèches).

Figure 3 : ChE activity in the forebody of $D$. merlangi, showing its association with the cerebral ganglia (CG), dorsal commissure (DC) and anterior and posterior longitudinal nerve cords (arrows). Note the innervation of the mouth region $(M)$ and musculature of the armed penis (PN). Scale bar, $100 \mu \mathrm{m}$.

structure, and the concentration of neural elements in association with the circular and longitudinal muscles in this region is clearly of significance in enabling this otherwise fairly sedentary parasite to explore adjacent regions of the host gill with respect to suitable feeding sites, as well as for locating partner worms for purposes of cross-insemination. This innervation of the "neck" region is part of the peripheral nervous system (PNS) which is typically plexiform in appearance and runs beneath the tegument, and in association with the subtegumental musculature, as an extensive subsurface network of fine fibres and related cell bodies (Fig. 4).

In places, the PNS sends fine nerve endings into the tegument where they terminate in a wide variety of putative sensory receptors (LYONS, 1973; FOURNIER \& COMBES, 1978). These include long uniciliate structures that project from the surface of the worm (Figs. 5, 6), most notably in regions around the mouth and buccal cavity and on the dorsal aspect of the haptor (HALTON, 1979). Experiments have shown that water turbulance generated mechanically over the surface of $D$. merlangi induces a rapid reflex response in the worm, most probably as an adaptation for survival on the gills of an active demersal fish like the whiting (MAULE et al., 1989a). In this regard, a long, flexible cilium would seem an ideal detector for monitoring flow-rate changes in the gill-ventilating water current. The PNS also provides a rich innervation to the various ducts and copulatory structures of the hermaphroditic reproductive system. 


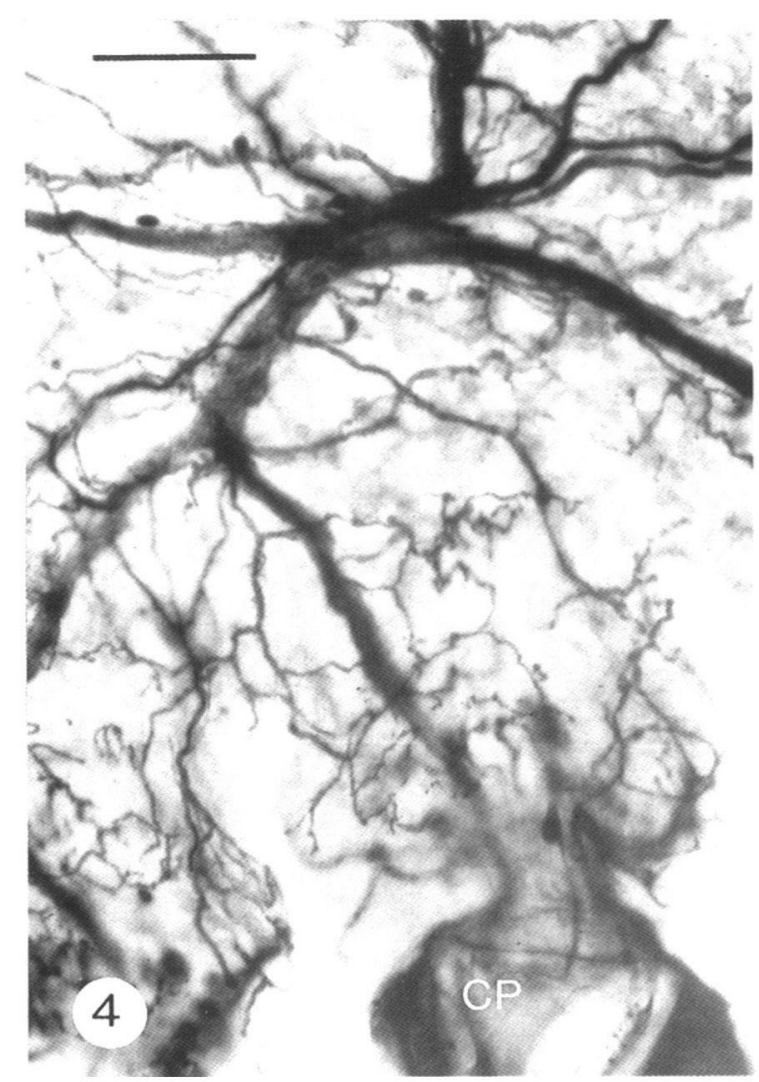

Figure 4 : Activité ChE dans la région haptoriale, montrant l'innervation CNS d'une pince (CP), ainsi que le réseau des fibres nerveuses périphériques dans cette région.

Figure 4 : ChE activity in the haptor region of $D$. merlangi, showing the CNS innervation of a clamp (CP), together with the extensive network of peripheral nerve fibres in this region. Scale bar, $100 \mu \mathrm{m}$.

Thus, all parts of the male and female ducting systems are underlain by a stratum of circular and longitudinal muscles, and these and the muscle fibres of the copulatory organs are provided with often extensive plexuses of nerves and associated terminals.

\section{Fine structure}

Electron microscopic studies of the cerebral ganglia in $D$. merlangi have revealed a central neuropile of non-myelinated nerve fibres and associated neurites. The fibres, contain at least two types of presumptive neurosecretory vesicles: small, clear vesicles (mean diameter [md], $40 \mathrm{~nm}$ ), reminiscent of known cholinergic vesicles, and dense-cored vesicles (md, $80 \mathrm{~nm}$ ) identical in appearance to aminergic and peptidergic vesicles; in addition, occasional large, lucent vesicles (md, $120 \mathrm{~nm}$ ) and large, dense vesicles ( $\mathrm{md}, 200 \mathrm{~nm}$ ) have been observed. More than one type of vesicle in varying combinations may be present in any one neurite, together with mitochondria (Fig. 7). Synapses in D. merlangiare predominantly asymmetrical, with a pronounced postsynaptic density, and most of them include small, clear vesicles that accumulate in rows against the presynaptic membrane. The synaptic cleft is approximately $20 \mathrm{~nm}$ in width and is filled with a moderately dense material (Fig. 7). Most of the synapses are shared in form, with a presynaptic terminal filled 
with vesicles abutting two postsynaptic fibres, each bearing postsynaptic densities. The neuronal cell bodies (somata) occupy the cortical region of the brain and are irregular in outline, with deep infoldings of plasma membrane, parallel arrays of GER, and indented nuclei. The cytoplasm is filled with unattached ribosomes, mitochondria and scattered populations of vesicles.

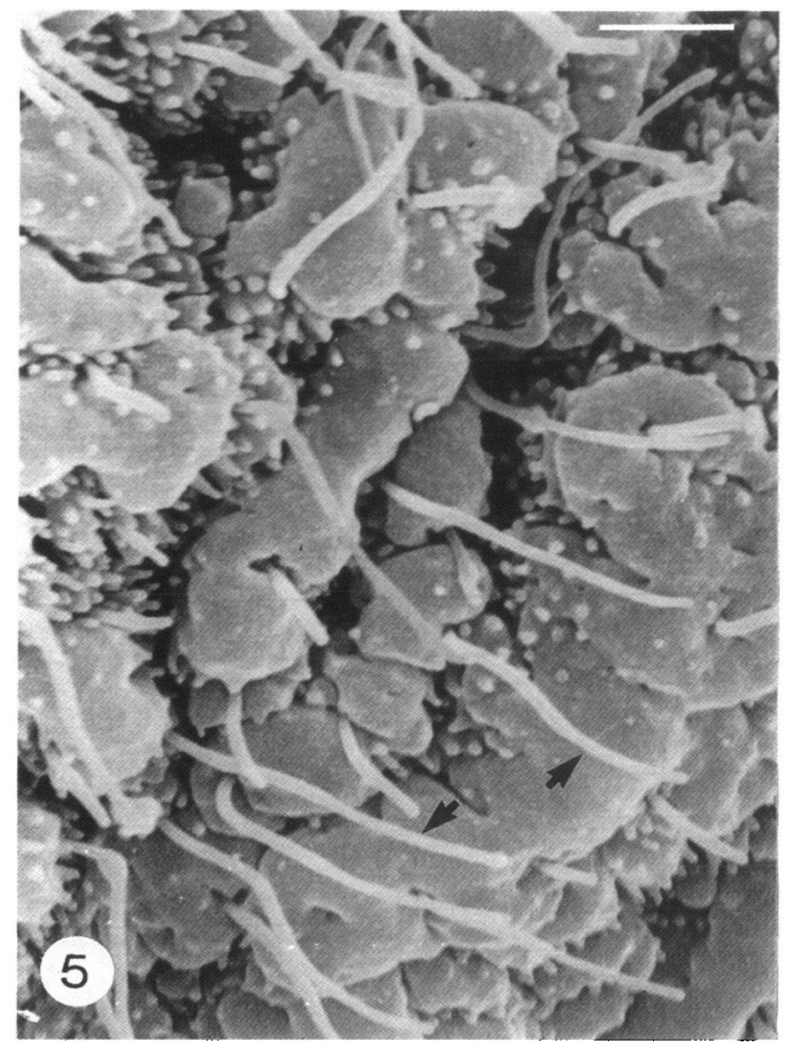

Figure 5 : Photographie au microscope à balayage montrant les structures monociliées, probablement sensorielles, situées à la surface du tégument autour de la bouche de $D$. merlangi.

Figure 5 : Scanning electron micrograph showing the numerous uniciliated, presumed sensory structures that project from the surface of the tegument surrounding the mouth of $D$. merlangi. Scale bar, $2 \mu \mathrm{m}$.

Nerve cords in $D$. merlangi consist of several large axons, supported by fibrous interstitial material, and filled with a lightly granular material in which there are neurotubules, mitochondria, and vesicles. Axo-axonal synapses (en passant type) are common and characterised by intermittent clusters of both clear and dense-cored vesicles positioned against adjacent axolemmas (Fig. 7). Large accumulations of dense-cored vesicles are not uncommon in axons and presumably account for the varicosities (beaded appearance) that characterise many of the peptidergic fibres found in immunocytochemical preparations. While there is a close spatial proximity of nerve and muscle elements in $D$. merlangi, 
identifiable synaptic connections between nerve and muscle are very infrequent. For example, in the somatic musculature of the forebody of the worm neural elements occupy the space between adjacent myofibres and while synapses can be found they have not been observed adjoining the sarcolemma. It may be that there are synaptoid release sites along the axon, such at the varicosities described above, from where myotropic factors can diffuse across interstitial tissue to interact with their target sites.

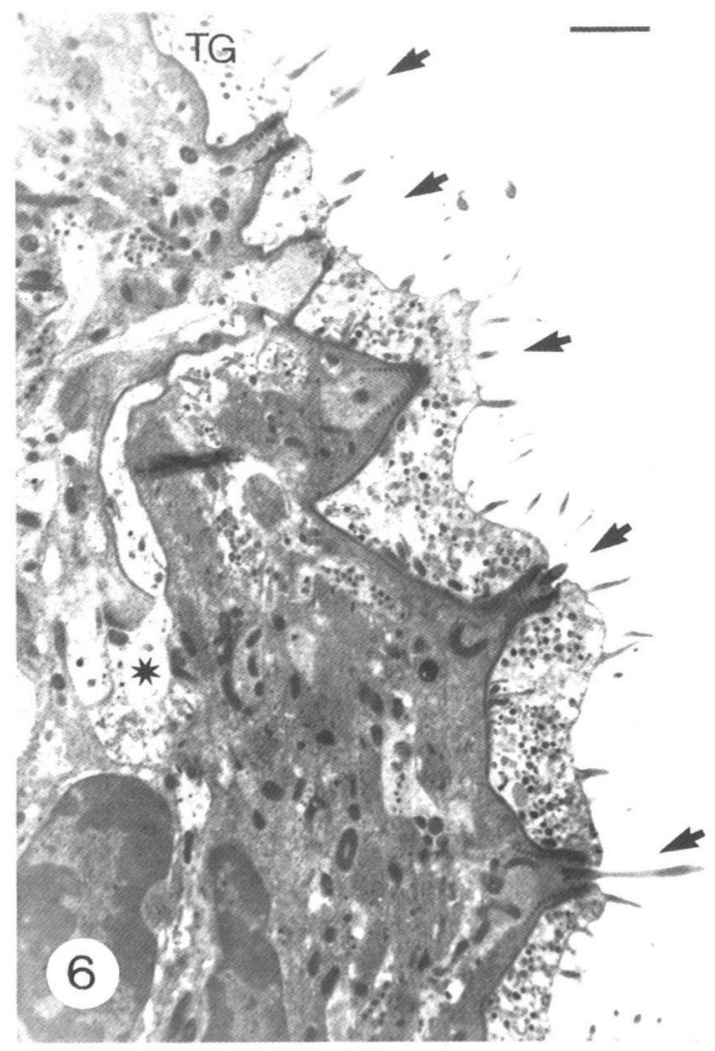

Figure 6 : Photographie en microscopie électronique à transmission du tégument (TG) dans la région de la bouche de $D$. merlangi montrant le profil de 5 structures probablement sensorielles avec leurs innervations.

Figure 6 : Transmission electron micrograph of the tegument (TG) in the mouth region of $D$. merlangi, showing profiles of 5 presumed sensory structures (arrows) and their associated innervation $\left({ }^{\star}\right)$. Scale bar, $1 \mu \mathrm{m}$.

\section{NEURONAL COMMUNICATION}

Most cells in the nervous system of animals communicate with one another and their cellular environment via extracellular signal molecules or chemical messengers, which they synthesise and secrete. Some 25 years ago, relatively few of these so-called first-messenger molecules were known and their actions were considered as relatively simple. Today, dozens of neuronal messengers are recognised, with receptor-mediated actions that can bring about not only short- and long-term changes in cellular excitability but which can also serve to influence events such as cellular metabolism, reproductive development, and gene expression. 


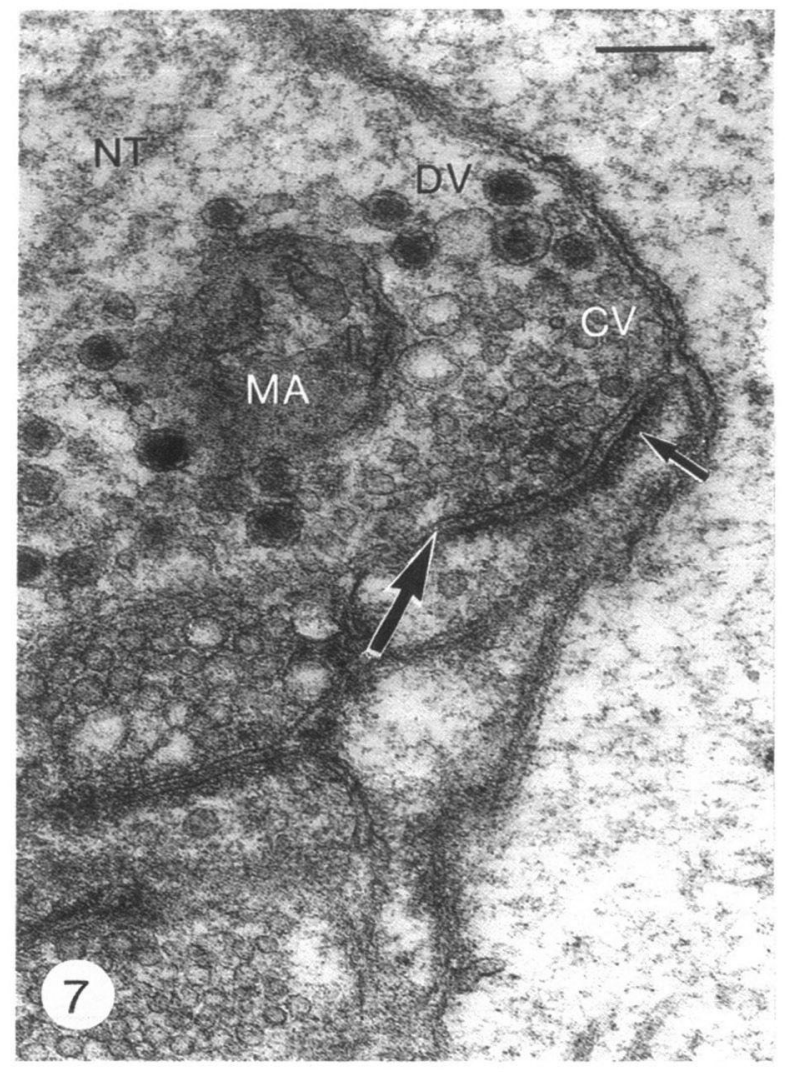

Figure 7 : Photographie en microscopie électronique à transmission d'une synapse axo-axonale (flèche large) dans un cordon nerveux chez $D$. merlangi.

Figure 7 : Transmission electron micrograph of an axo-axonal synapse (large arrow) in a nerve cord in $D$. merlangi. Note the postsynaptic density (small arrow) and presynaptic accumulations of both small, clear vesicles (CV) and dense-cored vesicles (DV). MA, mitochondrion; NT, neurotubules. Scale bar, $0.25 \mu \mathrm{m}$.

In general, all of these actions are effected by either (1) a rapid communication system, involving small-molecule neurotransmitters, or (2) an evolutionarily much older and slowersystem which uses as messenger molecules biologically-active peptides (regulatory peptides) of between 1-5 kDa molecular mass and 2-80 amino acid residues in length.

\section{Small-molecule neurotransmitters in monogeneans}

In mammals, the classical, small-molecule neurotransmitters such as acetylcholine (ACh), noradrenaline (NAdr), 5-hydroxytryptamine (5-HT; serotonin), and $\gamma$-aminobutyric acid (GABA) are synthesised in the nerve terminal and, when released, influence post-synaptic membrane potentials through a receptor-mediated opening and closing of ion channels. This fast system of intercellular communication is the basis of synaptic signalling in all known metazoan nervous systems.

\section{Cholinergic components}

The nervous system in D. merlangi displays an extensive cholinergic component, following staining for cholinesterase (ChE) activity as indirect evidence for the presence of acetylcholine 
Bull. Fr. Pêche Piscic. (1993) $328: 82-104 \quad-91-$

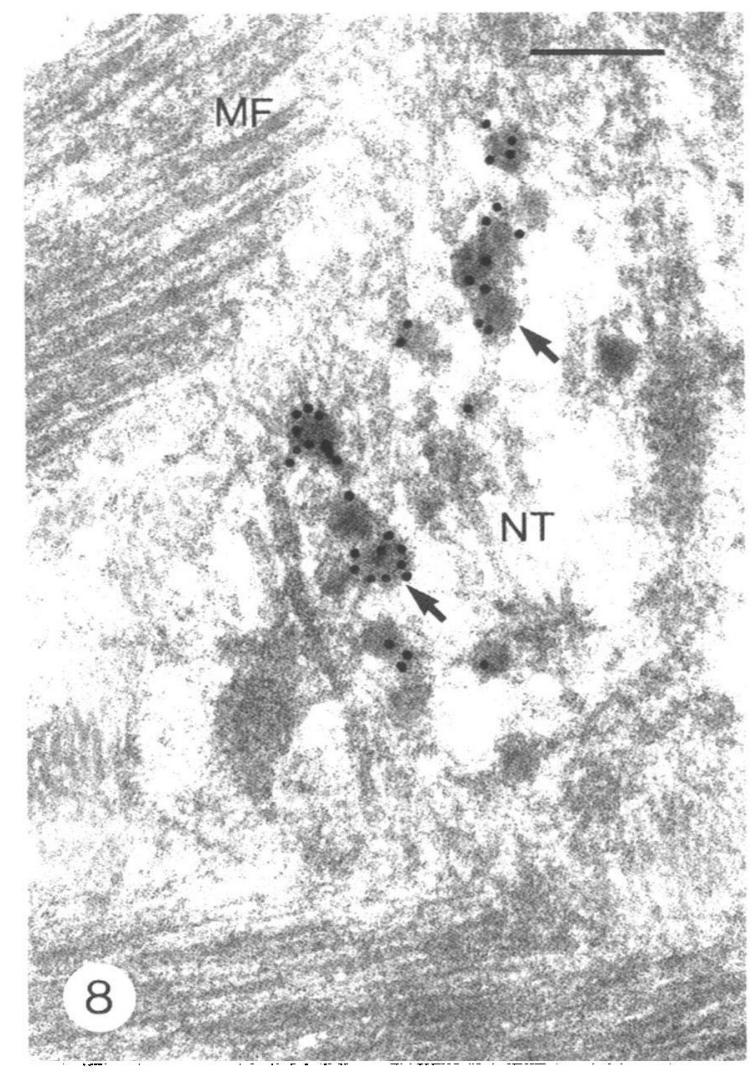

Figure 8 : Photographie en microscopie électronique à transmission montrant un marquage du neuropeptide F (NPF) à partir d'un antisérum couplé à l'or, concentré sur des vésicules denses (flèches) dans une terminaison nerveuse adjacente aux fibres musculaires (MF) de la paroi de l'ootype de D. merlangi.

Figure 8 : Transmission electron micrograph showing immunogold labelling with a neuropeptide F (NPF) antiserum concentrated over dense-cored vesicles (arrows) in a nerve terminal adjoining muscle fibres (MF) in the ootype wall of D. merlangi. NT, neurotubules. Scale bar, $0.25 \mu \mathrm{m}$.

(ACh). Cholinergic neurones account for a significant proportion of both the CNS and the PNS, including innervation of the musculature of the clamps, buccal suckers, pharynx, and penis (Figs. 2, 3, 4); interestingly, cholinergic nerves have not been found associated with the female reproductive tract of the worm (MAULE et al., 1990a,b).

It is well-documented that $A C h$ may be a putative inhibitory neurotransmitter in many parasitic platyhelminths, including $D$. merlangi (see SMYTH \& HALTON, 1983; SMYTH \& MCMANUS, 1989), and, indeed, atropine (an ACh antagonist) stimulates contractility in the worm in vitro. However, motility studies of the worm, using intact or strip-preparations, showed that in over 100 trials $\mathrm{ACh}$ failed to produce a consistent inhibitory or excitatory response (Fig. 9A) (MAULE et al., 1989a). Inconsistent or negative results were recorded also with a variety of known (mammalian) cholinergic agonists and antagonists, highlighting likely differences in selectivity and specificity between monogenean cholinoreceptors and those of higher vertebrates. 
A

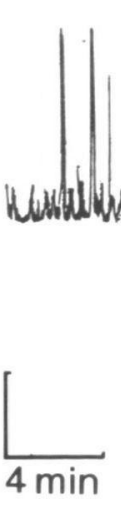

(i)

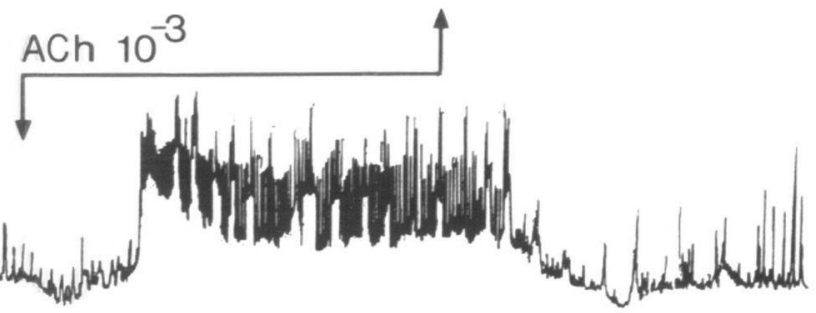

(ii)
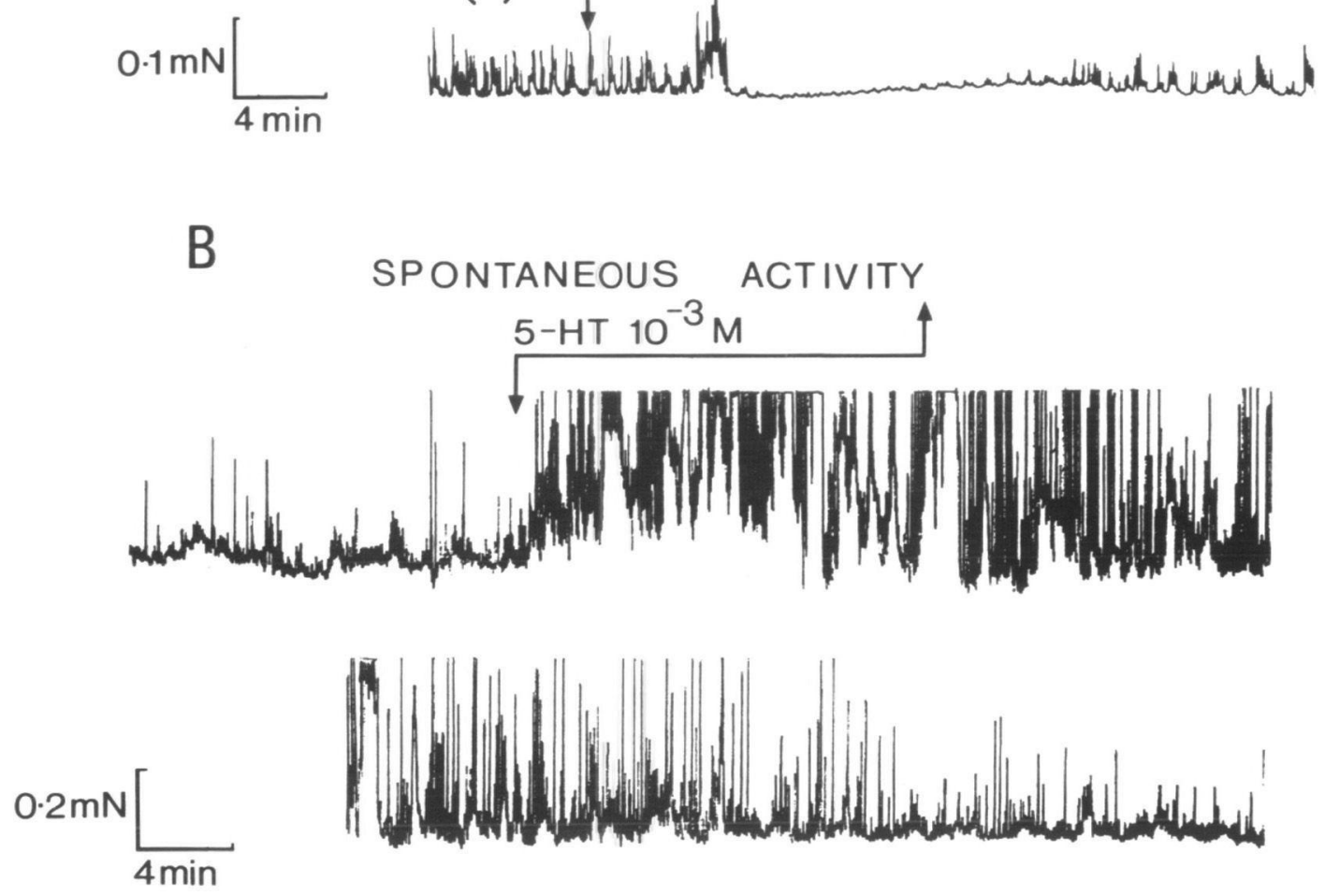

Figure 9 : Les effets des substances cholinergiques et aminergiques sur la contractilité spontanée de $D$. merlangi "in vitro".

Figure 9 : Effects of cholinergic and aminergic drugs on spontaneous contractility of $D$. merlangi in vitro. Each drug was added during the period indicated by the arrows above each record. (A). Acetylcholine $\left(1 \times 10^{-3} \mathrm{M}\right)$, showing both stimulatory (i) and inhibitory (ii) responses. (B). 5Hydroxytryptamine $\left(1 \times 10^{-3} \mathrm{M}\right)$, showing induced excitation. Upper and lower records are continuous. (After MAULE et al., 1989a).

\section{Serotoninergic components}

The presence of biogenic amines in the nervous system of monogeneans has been indicated by the demonstration of 5-HT-immunoreactivity, using immunocytochemical techniques and specific antisera (see Table l). Serotoninergic neurones, although widespread in $D$. merlangi, were found to have a less extensive distribution than cholinergic neurones (MAULE et al., 1990a). Within each of the paired cerebral ganglia, four interconnected multipolar serotoninergic somata were identified, and these were linked dorsally by a post-pharyngeal commissure (Fig. 10). Posteriorly, serotoninergic nerves comprised elements of the main longitudinal nerve cords 


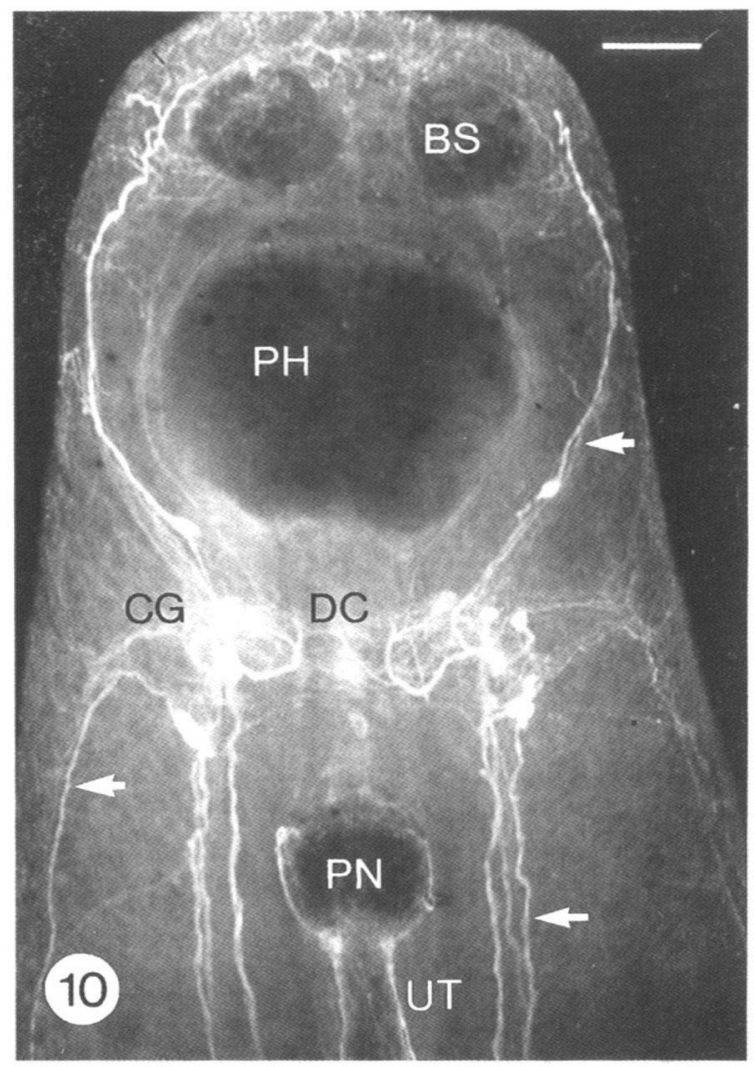

Figure 10 : Image de microscopie confocale en fluorescence montrant l'immunoréactivité 5-HT dans la partie antérieure de $D$. merlangi.

Figure 10 : Confocal scanning laser micrograph (CSLM) fluorescence image showing 5-HT-immunoreactivity (IR) in the forebody of D. merlangi. Note the immunoreactive cerebral ganglia (CG), dorsal commissure (DC), longitudinal nerve cords (arrows) and innervation of the uterus (UT) and penis (PN). BS, buccal sucker; PH, pharynx. Scale bar, $100 \mu \mathrm{m}$.

and formed fibre plexuses in association with the clamp ganglia. The PNS displayed a welldeveloped serotoninergic component, consisting of a nerve net which was particularly welldeveloped in the clamp and mouth regions.

While numerous biochemical functions have been advocated for 5 -HT in parasitic platyhelminths (see MANSOUR, 1984), based on those known from mammalian tissues, its most widely documented function has been that of an excitatory neurotransmitter. For example, observations by MAULE et al. (1989a) on somatic longitudinal muscle motility in vitro in $D$. merlangi, revealed that 5-HT increased the frequency, amplitude and baseline tension of spontaneous contractions (Fig. 9B). However, these excitatory effects could not be blocked with known 5-HT antagonists, such as methysergide or ketanserin, indicating, as for ACh, that any 5-HT receptors in the worm differ from those that have been characterised from mammals. Other biogenic amines, such as dopamine and noradrenaline, showed less pronounced stimulatory effects on worm motility and, again, known (mammalian) catecholamine-receptor blockers failed to alter any of the responses. 
All of the evidence to date suggests that, where examined, small-molecule neurotransmitters are widespread in the nervous system of monogeneans. However, while some putative neuromediators (eg 5-HT, dopamine, noradrenaline) induce excitatory effects on contractility in the worm, others (eg $\mathrm{ACh}$ ) are apparently more subtle in their action. It would seem unlikely that nerve terminals in $D$. merlangi synthesise and release only one signalling substance, but rather they secrete a cocktail of mediators, comprising small-molecule transmitters and regulatory peptides, the sum of whose interactions is the essence of synaptic communication in the nervous system (see below).

\section{Regulatory peptides in monogeneans}

Regulatory peptides differ from the small, fast-acting transmitters mentioned above in that their structures are encoded in the genome and produced in the cell body of the neurone, neurosecretory cell or endocrine cell by ribosomal protein synthesis. Many of them have originated by the duplication and divergence of ancestral genes and can therefore be classed into families

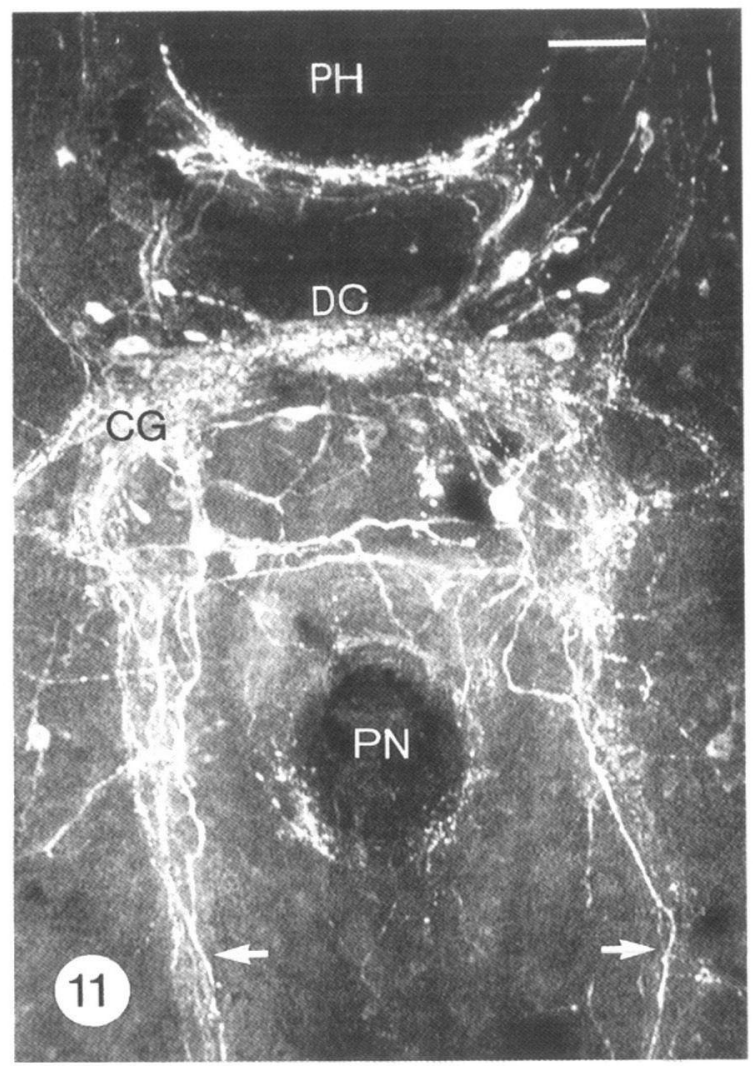

Figure 11 : Image de microscopie confocale en fluorescence du peptide YY (PYY)-IR dans la partie antérieure de $D$. merlangi, montrant la riche innervation peptidergique de la partie postérieure du pharynx (PH), des ganglions cérébraux (CG), de la commissure dorsale (DC) et des cordons nerveux longitudinaux (flèches).

Figure 11 : CSLM fluorescence image of peptide YY (PYY)-IR in the forebody of $D$. merlangi, showing the rich peptidergic innervation of the posterior portion of the pharynx (PH), and in the cerebral ganglia (CG), dorsal commissure (DC), and longitudinal nerve cords (arrows). PN, penis. Scale bar, $50 \mu \mathrm{m}$. 
of related structure; most of them are excised by specific site-directed proteolysis from larger precursor molecules (preproproteins), and in some cases more than one peptide messenger can be derived from a single precursor. Following their release from the peptidergic cell, the peptides may diffuse through tissues, as paracrine substances acting on neighbouring cells, or be carried by blood to more distant target tissues, thereby serving as hormones to mediate

Tableau II : Immunoréactivités peptidiques mises en évidence chez deux espèces de Monogènes.

Table II : Peptide immunoreactivities demonstrated in two species of monogenean parasite

\begin{tabular}{|c|c|c|}
\hline \multirow[t]{2}{*}{ Peptide antisera } & \multicolumn{2}{|c|}{ Parasites examined ${ }^{*}$} \\
\hline & $\begin{array}{c}\text { Gyrodactylus } \\
\text { (refs. } 1,2 \text { ) }\end{array}$ & $\begin{array}{c}\text { Diclidophora } \\
\text { (refs. 3-8) }\end{array}$ \\
\hline Pancreatic polypeptide (PP) & - & + \\
\hline Peptide $Y Y(P Y Y)$ & • & + \\
\hline Neuropeptide Y (NPY) & - & + \\
\hline Neuropeptide F (NPF) & - & + \\
\hline Glucagon & - & - \\
\hline Vasoactive intestinal polypeptide (VIP) & - & + \\
\hline Peptide histidine isoleucine (PHI) & • & - \\
\hline Gastrin & - & - \\
\hline Cholecystokinin (CCK) & $\bullet$ & + \\
\hline Gastrin releasing peptide (GRP) & - & - \\
\hline Substance $P$ & - & + \\
\hline Neurokinin A (NKA) & - & + \\
\hline Eledoisin & - & + \\
\hline Leu-enkephaklin & + & - \\
\hline$\beta$-Endorphin & - & - \\
\hline Adrenocorticotropic hormone $(\mathrm{ACTH})$ & $\bullet$ & - \\
\hline Neurotensin (NT) & $\bullet$ & - \\
\hline Somatostatin (SRIF) & $\bullet$ & - \\
\hline Urotensin I & + & - \\
\hline Growth hormone releasing factor (GRF) & + & $\bullet$ \\
\hline FMRFamide & + & + \\
\hline RFamide & + & - \\
\hline
\end{tabular}

${ }^{\star}+$, present; -, absent; $\bullet$, not tested.

References:

1. REUTER (1987) ; 2. REUTER (1988) ; 3. MAULE et al. (1989b) ; 4. MAULE et al. (1989c) ; 5. MAULE et al. (1989d) ; 6. MAULE et al. (1990a); 7. MAULE et al. (1990b) ; 8. MAULE et al. (1992b).

much longer-term trophic or behavioural effects. Peptide action is generally much slower than that of classical transmitters, both in onset of response and in duration, lasting in some cases for several minutes or even hours. Several peptides may co-exist with classical neurotransmitters in the same neurones, enabling post-synaptic interaction of the slower-acting peptide with the fast-acting classical transmitter. This overlap of the two basic systems of communication allows responses with widely varying time courses, and underscores the postsynaptic diversity and sophistication of intercellular signalling.

In general, peptide receptors are believed not to be in direct contact with ion channels per se, but rather they affect channels or the levels of intracellular second messengers, such 
as CAMP, through intermediary G-proteins. It is also worth noting that unicellular organisms and many non-neural cells in metazoans employ peptides as biochemical messengers, suggesting that as elements of intercellular communication regulatory peptides arose very early in evolution prior to the development of the nervous system. The texts of BRADFORD (1986) and SCHELLER \& HALL (1992) provide useful introductory accounts of the peptidergic system. What is becoming increasingly clear from evidence to date is that regulatory peptides represent the largest and most diverse class of signalling molecules in the animal kingdom, and that they exert a pervasive role in mediating changes not only of single function but also of initiating and orchestrating more complex cellular responses that culminate in the working of entire systems and associated behaviours. In short, they serve in homeostatic integration, enabling multicellular systems to perform complex functions in a coordinated fashion.

\section{Occurrence and nature of regulatory peptides in monogeneans}

Immunocytochemical methods, using well-characterised antisera raised to a wide range of vertebrate and invertebrate regulatory peptides, have demonstrated extensive regulatory peptide immunoreactivity in flatworm parasites, and have shown it to be restricted largely to

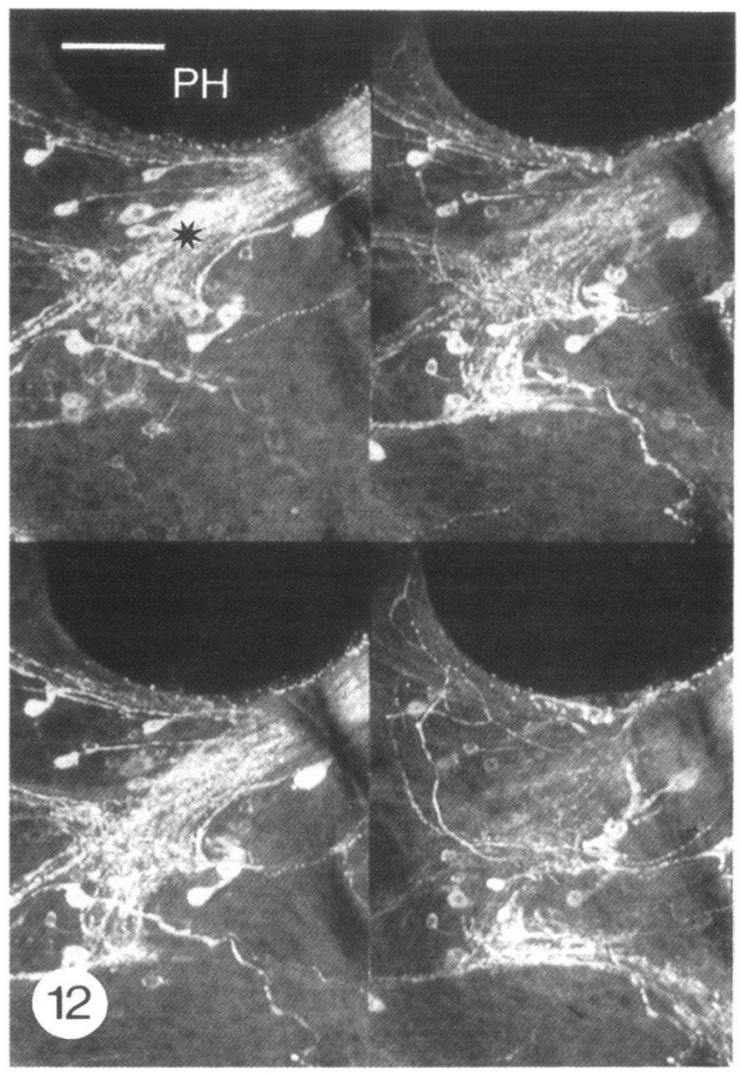

Figure 12 : Photographie composée de 4 coupes en microscopie confocale à travers un ganglion cérébral de $D$. merlangi.

Figure 12 : Composite micrograph of 4 CSLM optical sections through a cerebral ganglion of $D$. merlangi immunostained for PYY. Note that the ganglion has a central core of nerve fibres $\left({ }^{\star}\right.$, neuropile) and a peripheral arrangement of cell bodies (somata). PH, pharynx. Scale bar, $50 \mu \mathrm{m}$. 


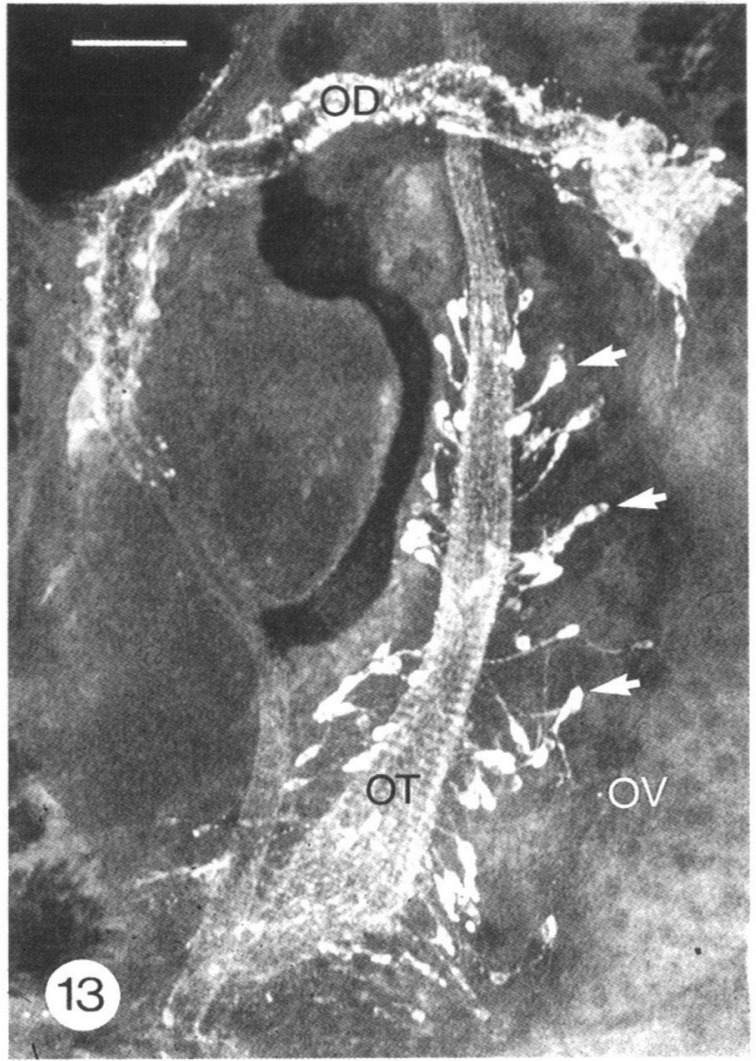

Figure 13 : Région de l'ootype et de la glande de Mehlis chez $D$. merlangi montrant le neuropeptide F (NPF-IR) dans les corps cellulaires (flèches) et les fibres innervant les parois de l'ootype et de l'oviducte.

Figure 13 : Ootype/Mehlis' gland region of $D$. merlangi showing neuropeptide $F$ (NPF)-IR in cell bodies (arrows) and fibres innervating the walls of the ootype (OT) and oviduct (OD). OV, ovary. Scale bar, $100 \mu \mathrm{m}$.

cells and fibres of the central and peripheral nervous systems (Figs. 11, 12, 13) (see reviews by HALTON et al., 1990; FAIRWEATHER \& HALTON, 1991). Homologues to some 26 mammalian and 4 invertebrate peptides have been identified so far, with reactivity for members of the neuropeptide $Y$ (NPY) superfamily (pancreatic polypeptide [PP], peptide $Y Y$ [PYY] and NPY), tachykinins such as substance $P$, and the invertebrate tetrapeptide, FMRFamide, occurring in representatives of most of the taxa investigated thus far, including $D$. merlangi (Table II).

The peptidergic portion of the nervous system in $D$. merlangiis well differentiated, accounting for the bulk of the CNS and PNS. Thus, numerous peptidergic neurones are present within the paired cerebral ganglia and provide fibre tracts that extend the length of the worm (Figs. $11,12)$; the clamps are innervated with ganglionic neurones, resembling those of the cerebral ganglia; and there is extensive peptidergic innervation to muscles of the penis and feeding apparatus (Fig. 11). In general then, the distribution pattern of peptidergic neurones in $D$. merlangi is comparable with that produced by cholinergic staining, with one notable difference: innervation of the female reproductive tract, including the egg-forming apparatus, appears to be exclusively peptidergic (see later).

By interfacing immunocytochemistry with confocal scanning laser microscopy (CSLM), it is possible to optically section whole-mount preparations of parasites (Fig. 12), that is, to 
collect images from different levels in the Z-axis, and then project these in perfect register to produce 3-dimensional reconstructions of immunoreactive structures (JOHNSTON et al., 1990). Mapping the peptidergic system in $D$. merlangi in this way, and then drawing it, has shown that it more closely resembles the cholinergic system than it does the aminergic (5-HT) system

A

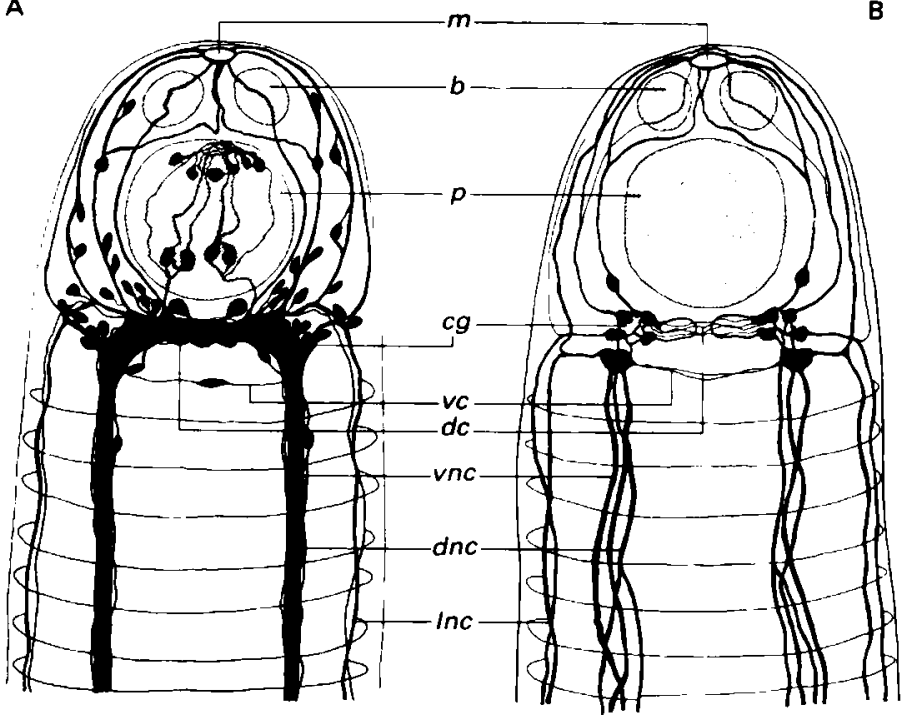

C

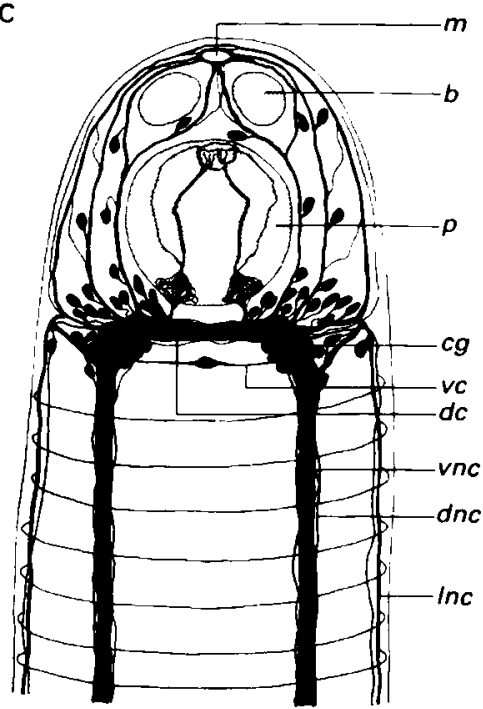

Figure 14 : Comparaison des composants cholinergiques (A), sérotoninergiques (B) et peptidergiques $(C)$ du système nerveux dans la partie antérieure du corps de $D$. merlangi.

Figure 14 : Comparisons of the cholinergic (A), serotoninergic (B) and peptidergic (C) components of the nervous system in the forebody of $D$. merlangi, based upon the staining patterns obtained for cholinesterase activity, 5HT-immunoreactivity, and for several regulatory peptides, respectively. Note that the cholinergic and peptidergic systems are comparable in organisation, whereas the serotoninergic system is distinctive in construction. b, Buccal sucker; $p$, pharynx; $m$, mouth; cg, cerebral ganglia; dc, dorsal commissure; vc, ventral commissure; vnc, ventral nerve cord; dnc, dorsal nerve cord; Inc, lateral nerve cord. (After MAULE et al., 1990a).

(Fig. 14). CSLM has also enabled the monitoring of neuroanatomical and neurochemical changes during parasite ontogeny. Such work has indicated that certain neuropeptides may be expressed by certain neurones at particular times in development, indicating that they are perhaps stage-specific key messengers in triggering development. Overall, the immunocytochemical data have shown that in flatworms, neuropeptides predominate over small molecular weight classical neurotransmitters, and such findings support the view that the platyhelminth nervous system serves a neuroendocrine function for coordinating important physiological and behavioural activities.

\section{Host-parasite differences in regulatory peptides}

Characterisation of parasite neuropeptides in parallel with the analogous peptides of the host, through comparative HPLC analyses, has in a number of host-parasite systems exposed differences in neuropeptide biochemistry (see SHAW \& JOHNSTON, 1991 for a 


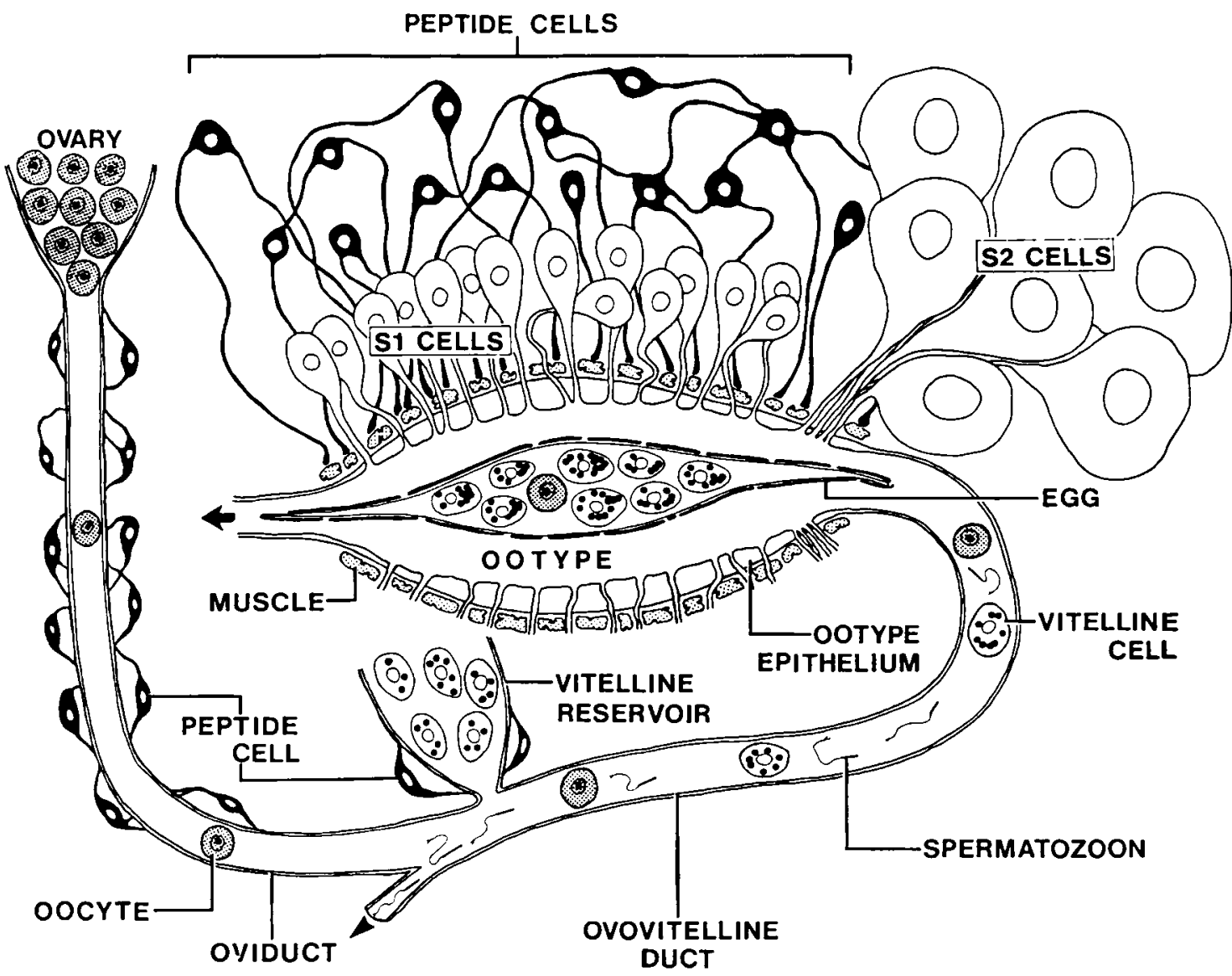

Figure 15 : Schéma montrant les relations entre les cellules peptidoimmunoréactives et le muscle des conduits de l'appareil reproducteur femelle de $D$. merlangi.

Figure 15 : Schematic diagram showing the close spatial relationship of peptideimmunoreactive cells with the muscle of the proximal ducts of the female reproductive apparatus of $D$. merlangi. Note that the $S 1$ and $S 2$ cells comprise Mehlis' gland, and that, once formed, the egg passes from the ootype into the uterus (arrow). (After MAULE et al., 1990b).

review). In D. merlangi, for example, immunochemical characterisation of the tachykinin-immunoreactivity identified in the nervous system by immunocytochemistry (Table II), has established the presence of two native parasite peptides in extracts of the worm (MAULE et al., 1989b). Of the two tachykinins characterised, one was substance P-like and the other was neurokinin A-like; however, neither was identical to previously identified tachykinins. Comparison of the parasite tachykinins with those identified in tissue extracts of its host-fish, the whiting (Merlangius merlangus), revealed them to have different molecular weights and hydrophobic properties. As already stated, the most extensive and intense immunoreactivity for regulatory peptides in flatworm parasites, including $D$. merlangi, is with antisera to the vertebrate NPY superfamily of peptides, and in particular with antisera raised to the C-terminal hexapeptide amide of PP. Chromatographic characterisation of the PP-immunoreactive peptide in $D$. merlangiestablished, as with the tachykinin peptides in the parasite, that it is structurally different from analogous peptides in the host (Maule etal., 1989c). Such results indicate that host and parasite neuropeptides, while displaying conservation of their bioactive domains, as shown by their cross-reaction with 
antisera directed to these sites, have nevertheless undergone separate evolutionary pathways. These data also demonstrate the parasite's ability to perform de novosynthesis of neuropeptides, rather than acquiring them from the host.

\section{Neuropeptide $F$ (NPF) and evidence for its occurrence in monogeneans}

Isolation and structural analysis of the PP-immunoreactivity found in extracts of the cestode, Moniezia expansa have revealed it to be due to a 39-residue peptide sharing Cterminal structural homology with PP (MAULE et al., 1991). The peptide has been designated neuropeptide $F$ (Moniezia expansa), in view of its homology with mammalian NPY and the fact that it has a $C$-terminal amidated phenylalanine $(=F$, using a single-letter notation for the amino acids), rather than a tyrosine $(=Y)$. Neuropeptide $F(N P F)$ is an authentic invertebrate neuropeptide and the first native flatworm neuropeptide to be discovered; from measurements of its immunoreactivity, it is also by far the most abundant of all peptides recovered from parasitic platyhelminths. NPF analogues have since been sequenced from the terrestrial turbellarian, Artioposthia triangulata (by CURRY et al., 1992) and the pulmonate snail, Helix aspersa (by LEUNG et al., 1992) and, collectively, they represent a genuine invertebrate regulatory peptide family.

Evidence for the presence of an NPF-like peptide in D. merlangi has come from chromatographic analyses of a peptide in the worm, which cross-reacted with C-terminally directed antisera and which has an apparent molecular mass of 4200-4700 daltons - that is, within the range of known NPY superfamily peptides, including NPF (M. expansa) (MAULE et al., 1992a). The purified peptide was found to be C-terminally amidated - a characteristic of all NPY superfamily peptides - and, using a battery of NPY superfamily antisera, that it had C-terminal characteristics more analogous to those of PP than those of NPY and PYY. However, the parasite peptide failed to cross-react with a non-C-terminal PP antiserum under the competitive conditions of radioimmunoassay, indicating that it was not an authentic mammalian $P P$. This was confirmed following the generation of specific C-terminally directed NPF antisera from NPF (M. expansa) which identified the $D$. merlangi PP-immunoreactivity as being due to an NPF-related peptide which cross-reacts with C-terminally directed PP antisera (MAULE et al., 1992a). The fact that the $D$. merlangi peptide did not cross-react with N-terminally directed NPF ( $M$. expansa) antisera indicates that NPF (D. merlangi), while not identical with NPF (M. expansa), is structurally similar in its C-terminus. As yet, it has not been possible to purify sufficient NPF peptide from $D$. merlangi to allow either its sequencing or amino acid analysis. Although a parasite NPF has been demonstrated unequivocally only in the cestode, $M$. expansa, it now seems likely that all of the PP-like immunoreactivity found in other lower invertebrates, including monogeneans, will prove to be due to NPF-related peptides.

\section{NEUROMEDIATORS AND REPRODUCTION IN MONOGENEANS}

Since chance largely determines the transmission and successful completion of the parasite life cycle, it would seem that the odds in favour of parasite survival are not very high. However, parasites in general are impressively fecund and are invariably characterised by a fairly prodigious egg output and a reproductive biology of marked complexity. This is particularly true of most parasitic flatworms - though not necessarily of all monogeneans, many of which have fairly simple life cycles and produce relatively moderate numbers of eggs. Nonetheless, all known monogeneans are hermaphroditic and their reproductive system probably accounts for the bulk of their metabolic activity and certainly their body space.

Flatworms were the first group of metazoans to develop complex reproductive structures comprising, basically, gonads and an intricate series of muscularised reproductive ducts and associated glands. As already indicated, most regulatory peptides demonstrable in flatworms occur in the central and peripheral nervous systems, and so not surprisingly peptidergic elements occuralso in those components of the PNS that innervate the reproductive system (see HALTON et al., 1990; FAIRWEATHER \& HALTON, 1991; GUSTAFSSON, 1992). Thus, in the male system, PP-like peptides have been found in the nerve plexuses innervating the muscle of the seminal vesicle, cirrus (or penis), cirrus sac and genital atrium. Immunoreactivities for several peptides have been recorded within the female reproductive apparatus, with members of the NPY peptide superfamily (NPY, PP, PYY), tachykinins (substance $P$, neurokinin A, eledoisin), FMRFamide, and gastrin/cholecystokinin occurring in fibres and associated somata in the 
walls of the oviduct, vitelline reservoir and ovovitelline duct. However, in all flatworm parasites examined, including monogeneans, the most intense peptide immunoreactivity has been found in cells and fibres associated with the egg chamber or ootype (Fig. 13), a finding which points to an involvement of peptides in the egg-forming sequence.

\section{Regulatory peptide involvement in egg formation}

The mechanism that regulates the assembly and production of eggs in monogeneans resides in the egg-forming apparatus or "oogenotop" (Fig. 15). This comprises largely the eggchamber or ootype in which "...the egg is formed as a result of a series of beautifully controlled reactions involving the release of ova (or oocytes), spermatozoa, vitelline cells and secretions of the enigmatic Mehlis' gland." (SMYTH \& HALTON, 1983). All of these components are transported to the ootype as a result of a highly-ordered series of rhythmical contractions of the muscle in the walls of the ducting system: oviduct, seminal receptacle, ovo-vitelline duct and the ootype itself. The circular muscles of the ootype are particularly well-developed. Sphincter muscles operate to release an oocyte from the oviduct, and a number of vitelline cells from the vitelline reservoir; these pass to the ootype along with spermatozoa. Here, in the presence of an oocyte and sperm, the vitelline cells release their shell-protein droplets which then disperse peripherally to coalesce around the cell cluster to form the eggshell.

A series of gland cells, collectively known as Mehlis' gland, surrounds the ootype, and their secretions pass into its lumen (Fig. 15). The role(s) of these secretions is(are) as yet unknown, but there is some evidence in other flatworms that they trigger a calcium-dependent, exocytotic release of the shell protein, as well as provide a viscous "template" for its deposition and fusion into an eggshell (WELLS \& CORDINGLEY, 1991). Observations on egg formation in the ootype of living specimens of monogeneans by a number of workers, refer to vigorous churning and kneading movements of the ootype wall. Whether these contractions facilitate shell-protein release and dispersal is unclear, but they may help mould the egg to its characteristic shape. Sphincter muscles regulate the passage of newly-formed eggs from the ootype into the uterus. A comprehensive review of monogenean eggs, including their assembly, is provided by KEARN (1986).

How egg formation in monogeneans, or indeed in flatworms in general, is controlled, has yet to be determined, but the mechanism undoubtedly resides in the nerve and muscle elements that invest the ootype wall and associated ducts. More precisely, it is the innervation of these structures that likely initiates and controls the successive events of egg assembly. In this respect, a consistent finding in immunocytochemical investigations of regulatory peptides in flatworm parasites is that this innervation is predominantly peptidergic. Moreover, peptidergic cells, corresponding to nerve plexuses, are invariably associated with the ootype/Mehlis' gland cell complex. In D. merlangi, a heterogeneous population of some 100 uni-, bi, and multi-polar neurones, interconnected by axonal extensions, converge on the ootype wall and asssociated ducts (Fig. 15). These cells, as distinct from the Mehlis' gland cells, are immunoreactive for members of the NPY superfamily and for FMRFamide. Their strategic positioning at the exit of the vitelline reservoir and around the ootype suggest their contents may have a regulatory role in egg assembly and reproductive function.

Ultrastructural examination of these cells has revealed a fine structure consistent with that of a secretory cell engaged in the synthesis and export of protein via dense-cored vesicles (HALTON et al., 1991). The vesicles, measuring approximately $80-100 \mathrm{~nm}$ in diameter, fill the axonal extensions of the cell and come to accumulate in the swollen cell terminals that form synaptic appositions with the smooth muscle fibres of the ootype wall. Using immunogold labelling techniques, the peptide content of the vesicles has been shown to be immunoreactive with antisera raised to the C-terminal hexapeptide amide of PP.

The use of double-immunogold labelling at ultrastructural level has revealed an identical distribution of PP and FMRFamide immunoreactivities in the dense-cored inclusions, indicating cross-reactivity of antisera (BRENNAN et al., 1993). Preadsorption experiments, using the recently discovered flatworm neuropeptide $F$ (Moniezia expansa) (NPF) have shown that any co-localisation of PP and FMRFamide immunoreactivities can be explained by cross-reactivity of these C-terminally directed antisera with NPF. Subsequently, experiments using antisera directed to the intact synthetic NPF (M. expansa) (residues 1-39) or to the C-terminal decapeptide (residues 30-39) have shown that the distribution pattern of immunostaining for NPF in $D$. 
merlangi, both at light- and electron-microscopic levels, mirrored exactly the staining patterns for PP and FMRFamide (MAULE et al., 1992b). These data confirm the biochemical findings described earlier that, in common with other flatworms examined, it is NPF which is the most abundant, native neuropeptide demonstrable in monogenean parasites and that, where examined, it dominates the nervous system including innervation of the egg chamber (Figs. 8, 13). The fact that analogous neuropeptides have now been detected in all of the major invertebrate phyla investigated (coelenterates, platyhelminths, annelids, molluscs, insects), establishes NPF as an evolutionarily-ancient molecule that likely subserves important physiological functions as a neuronal mediator in parasite reproduction. Such functions have yet to be investigated but are likely to include regulation of the synchronised motility of the duct muscles and sphincters that are responsible for bringing to the ootype the components of each egg, its assembly and shaping, and its release, when formed, to the uterus; additionally, NPF may exert a paracrinelike influence on the secretory activity of the Mehlis' gland (HALTON et al., 1991).

\section{CONCLUSION}

It is becoming increasingly apparent that the nervous system in flatworms, while simple in plan of construction and low in neuronal number, is chemically as complex as that in many of the higher-evolved invertebrate organisms. Further work on the nature and distribution of putative neuronal mediators in other monogeneans is likely in future, and will obviously be useful not only in extending studies on monogenean nervous systems per se, but also in exploring features such as the impact of parasitism on flatworm neurochemistry; phylogenetic links between flatworm groups; and host-parasite differences in neurochemistry, which could lead to the development of control strategies through research into novel anthelmintics.

\section{REFERENCES}

BRADFORD H.F., 1986. Chemical neurobiology. W.H. Freeman \& Company, New York, $507 \mathrm{p}$.

BRENNAN G.P., HALTON D.W., MAULE A.G., SHAW C., JOHNSTON C.F., MOORE S., FAIRWEATHER I., 1993. Immunoelectron microscopical studies of regulatory peptides in the nervous system of the monogenean parasite, Diclidophora merlangi. Parasitology, 106, 171-176.

CURRY J., SHAW C., JOHNSTON C.F., THIM L., BUCHANAN K.D., 1992. Neuropeptide F : primary structure from the turbellarian Artioposthia triangulata. Comp. Biochem. Physiol., 101C, 269-274.

FAIRWEATHER I., HALTON D.W., 1991. Neuropeptides in platyhelminths. Parasitology, 102, S77-S92.

FOURNIER A., COMBES C., 1978. Structure of photoreceptors of Polystoma integerrimum (Platyhelminthes, Monogenea). Zoomorphologie, 91, 147-155.

GUSTAFSSON M.K.S., 1990. The cells of a cestode - Diphyllobothrium dendriticum as a model in cell biology. In GUSTAFSSON M.K.S., REUTER M. (eds), The early brian. Proceedings of the Symposium of "Invertebrate Neurobiology". Acta Acad. Aboensis Ser $B, 50,13-44$.

GUSTAFSSON M.K.S., 1992. The neuroanatomy of parasitic flatworms. Adv. Neuroimmunol., 2, 267-286.

HALTON D.W., JENNINGS J.B., 1964. Demonstration of the nervous system in the monogenetic trematode Diplozoon paradoxum Nordmann by the indoxyl acetate method for esterases. Nature, Lond., 202, 510-511.

HALTON D.W., MORRIS G.P., 1969. Occurrence of cholinesterase and ciliated sensory structures in a fish gill fluke, Diclidophora merlangi (Trematoda: Monogenea). $Z$. Parasitenk., 33, 21-30. 
HALTON D.W., 1979. The surface topography of a monogenean, Diclidophora merlangi revealed by scanning electron microscopy. $Z$. Parasitenk., 61, 1-12.

HALTON D.W., MAULE A.G., JOHNSTON C.F., FAIRWEATHER I., 1987. Occurrence of 5hydroxytryptamine (serotonin) in the nervous system of the monogenean, Diclidophora merlangi. Parasitol. Res., 74, 151-154.

HALTON D.W., FAIRWEATHER I., SHAW C., JOHNSTON C.F., 1990. Regulatory peptides in parasitic platyhelminths. Parasitol. Today, 6, 284-290.

HALTON D.W., BRENNAN G.P., MAULE A.G., SHAW C., JOHNSTON C.F., FAIRWEATHER I., 1991. The ultrastructure and immunogold labelling of pancreatic polypeptide-immunoreactive cells associated with the egg-forming apparatus of a monogenean parasite, Diclidophora merlangi. Parasitology, 102, 429-436.

HALTON D.W., SHAW C., MAULE A.G., JOHNSTON C.F., FAIRWEATHER I., 1992. Peptidergic messengers: a new perspective of the nervous system of parasitic platyhelminths. J. Parasitol., 78, 179-193.

JOHNSTON C.F., SHAW C., HALTON D.W., FAIRWEATHER I. 1990. Confocal scanning laser microscopy and helminth neuroanatomy. Parasitol. Today, 6, 305-308.

KEARN G.C., 1986. The eggs of monogeneans. Adv. Parasitol. 25, 175-273.

LEUNG P.S., SHAW C., MAULE A.G., THIM L., JOHNSTON C.F., IRVINE G.B., 1992. The primary structure of neuropeptide $F$ (NPF) from the garden snail, Helix aspersa. Regul. Pept. 41, 71-81.

LYONS K.M., 1973. The epidermis and sense organs of the Monogenea and some related groups. Adv. Parasitol., 11, 193-232.

LYUKSHINA L.M., SHISHOV B.A., 1988. Biogenic amines in the nervous system of Eudiplozoon nipponicum (Monogenea). In SAKHAROV D.A. (ed), Simple nervous systems, 173-176, Nauka, Moscow (in Russian).

MANSOUR T.E., 1984. Serotonin receptors in parasitic worms. Adv. Parasitol., 23, 1- 36.

MAULE A.G., HALTON D.W., ALLEN J.M., FAIRWEATHER I., 1989a. Studies on motility in vitro of an ectoparasitic monogenean, Diclidophora merlangi. Parasitology, 98, 85-93.

MAULE A.G., SHAW C., HALTON D.W., JOHNSTON C.F., FAIRWEATHER I., BUCHANAN K D., 1989b. Tachykinin immunoreactivity in the parasitic flatworm Diclidophora merlangi and its fish host the whiting (Merlangius merlangus) : radioimmunoassay and chromatographic characterisation using region-specific substance $P$ and neurokinin A antisera. Comp. Biochem. Physiol., 94C, 533-541.

MAULE A.G., SHAW C., HALTON D.W., JOHNSTON C.F., FAIRWEATHER I., 1989c. Localization, quantification and characterization of pancreatic polypeptide immunoreactivity in the parasitic flatworm Diclidiphora merlangi and its fish host (Merlangius merlangus). Gen. Comp. Endocrinol., 74, 50-56.

MAULE A.G., HALTON D.W., JOHNSTON C.F., FAIRWEATHER 1., SHAW C., 1989d. Immunocytochemical demonstration of neuropeptides in the fish-gill parasite, Diclidophora merlangi (Monogenoidea). Int. J. Parasitol., 19, 307-316.

MAULE A.G., HALTON D.W., JOHNSTON C.F., SHAW C., FAIRWEATHER I., 1990a. The serotoninergic, cholinergic and peptidergic components of the nervous system in the monogenean parasite, Diclidophora merlangi : a cytochemical study. Parasitology, $100,255-273$.

MAULE A.G., HALTON D.W., JOHNSTON C.F., SHAW C., FAIRWEATHER I., 1990b. A cytochemical study of the serotoninergic, cholinergic and peptidergic components of the reproductive system in the monogenean parasite, Diclidophora merlangi. Parasitol. Res., 76, 409-419. 
MAULE A.G., SHAW C., HALTON D.W., THIM L., JOHNSTON C.F., FAIRWEATHER I., BUCHANAN K.D., 1991. Neuropeptide $F$ : a novel parasitic flatworm regulatory peptide from Moniezia expansa (Cestoda : Cyclophyllidea). Parasitology, 102, 309-316.

MAULE A.G., SHAW C., HALTON D.W., JOHNSTON C.F., FAIRWEATHER I., $1992 a$. Immunochemical and chromatographic analyses of a neuropeptide from the monogenean parasite, Diclidophora merlangi : evolutionary aspects of the neuropeptide Y superfamily. Comp. Biochem. Physiol., 102C, 517-522.

MAULE A.G., BRENNAN G.P., HALTON D.W., SHAW C., JOHNSTON C.F., MOORE S., 1992b. Neuropeptide F-immunoreactivity in the monogenean parasite Diclidophora merlangi. Parasitol. Res., 78, 655-660.

MCKAY D.M., HALTON D.W., MAULE A.G., JOHNSTON C.F., SHAW C., FAIRWEATHER I., 1991. Putative neurotransmitters in two monogeneans. Helminthologia, 28, 75-81.

RAHEMO Z.I.F., GORGEES N.S., 1987. Studies on the nervous system of Polystoma integerrimum as revealed by acetylthiocholine activity. Parasitol. Res., 73, 234-239.

REUTER M., 1987. Immunocytochemical demonstration of serotonin and neuropeptides in nervous system of Gyrodactylus salaris (Monogenea). Acta. Zool. (Stockh.), 68, 187- 193.

REUTER M., 1988. Development and organization of nervous systems visualised by immunocytochemistry in three flatworm species. Prog. Zool., 36, 181-184.

SHAW C., JOHNSTON C.F., 1991. Role of regulatory peptides in parasitic platyhelminths and their vertebrate hosts : possible novel factors in host-parasite interactions. Parasitology, 102, S93-S105.

SMYTH J.D., HALTON D.W., 1983. The physiology of trematodes. Cambridge University Press, Cambridge, $446 \mathrm{p}$.

SMYTH J.D., MCMANUS D.P., 1989. The physiology and biochemistry of cestodes. Cambridge University Press, Cambridge, $398 \mathrm{p}$.

SCHELLER R.H., HALL Z.W., 1992. Chemical messengers at synapses. In HALL Z.W. (ed). Molecular neurobiology, 119-147, Sinauer, Sunderland, Massachusetts.

TERENINA N.B., OVERCHUK E.B., 1988. Serotonin, dopamine in extracts from tissues of Polystoma integerrimum (Monogenea). Parasitology, 22, 160-164.

TIEKOTTER K.L., 1988. Histofluoerscent and ultrastructural identification of aminergic processes in the opisthaptor of the marine monogene, Microcotyle sebastis (Polyopisthocotylea : Microcotylinae). Proc. Helminth. Soc. Wash., 55, 229-245.

WELLS K.E., CORDINGLEY J.S., 1991. Schistosoma mansoni : eggshell formation is regulated by $\mathrm{pH}$ and calcium. Exp. Parasitol., 73, 295-310. 